\title{
On Construction of the Mode of Deep College- enterprise Cooperation in Application-oriented Colleges in China
}

\author{
Deyun Yang \\ Department of Information Science and Technology \\ Taishan University \\ Taian City, China \\ yangdeyun163@163.com
}

\begin{abstract}
In recent years, local colleges have become an important part of undergraduate training in China. However there are some problems in the training of talents in the application-oriented undergraduate colleges. First we analyze the cause of the problems, then prefer a construction on the mode of deep college-enterprise cooperation in application-oriented colleges.
\end{abstract}

Keywords-Deep College-enterprise Cooperation; Application-oriented Colleges; Application-oriented talents training; Mode; working mechanism.

\section{THE CURRENT SITUATION OF COLLEGE-ENTERPRISE COOPERATION IN APPLICATION-ORIENTED COLLEGES IN CHINA}

In the popularization of higher education in China, local colleges have been vigorously developed. According to the Ministry of Education in 2013 on the number of higher education schools, China has 1060 Local colleges and universities directly under the central departments. New local colleges, especially in recent years, has become an important part of undergraduate training. This has made outstanding contributions to higher education to "mass education" and to the benefit of more students. But the development of these colleges is also facing new challenges.

As a middle part of the higher education system, the local undergraduate colleges are in the predicament of "too choosy", and their academic research level, teaching conditions and quality of personnel training have certain limitations. The colleges have not yet effectively solved the contradiction between the local economic development and the diversity of talent needs, and did not break through the bottleneck between social expectation and poor quality of student training. How to break through the above bottleneck, improve the teaching environment, optimize the educational resources, increase the connection with enterprises and industries, achieve the real sense of industrial docking, and cultivate high-quality application-oriented talents that meet the needs of local economic development has become an urgent problem.

The information industry is a new industry with computer technology as its main tool to expand the human information function. It is one of the most promising emerging industries, and has become the basic industry of developed countries and even the world economy. The level of development of the information industry determines the level of a country's scientific and technological innovation and its comprehensive competitiveness in the international market. Computer technology has obvious comprehensive characteristics, and it is closely integrated with software engineering, electronic engineering, mechanical engineering, modern communication technology, applied physics and mathematics, and has developed rapidly. At present, more than $90 \%$ of the local colleges in China have computer majors, the quality of their students is significantly lower than the national key universities, but the construction of such majors has followed the comprehensive colleges and universities, and even 985 Universities. From the curriculum system to the construction of education and teaching model, there is a great degree of singleness and convergence, which leads to the low quality of talent training.

\section{THE REQUIREMENTS OF THE STATE FOR THE TRANSFORMATION OF APPLICATION-ORIENTED COLLEGES}

In June 2013, the Ministry of Education issued a notice on the comprehensive reform of the first batch of undergraduate majors in local colleges, which started the implementation of the "comprehensive reform pilot project" and approved 550 reform pilots for the undergraduate majors. And the major "software engineering" of Taishan University was identified as the first batch of comprehensive reform pilot major. After that, we have carried out a great deal of research and achieved some useful results.

At the executive meeting of the State Council held in February 26, 2014, Premier Li Keqiang of the State Council, in particular, offered to guide the transformation of a number of ordinary undergraduate colleges to become the application-oriented colleges. In March 2014, the former Minister of education, Yuan Guiren, said the focus was on promoting the transformation of a number of local colleges into applied technology colleges to train more high-quality technical workers. In October 2016, Chen Baosheng, Minister of education, asked for experimental practice and training of college students, especially in innovation, entrepreneurship practice, expanding channels and building platforms, increasing investment and optimizing services, to educate college students in practice. There are more than 600 local colleges in the country facing transformation and reform, and even some of the "211" universities will 
also face transformation into application-oriented Universities. Therefore, with the development of higher education in our country, positioning of application-oriented colleges has gradually been established as application-oriented talents training. Under the new situation, the development of applied talents and the cultivation of high-level practical talents have become the orientation and objective of many universities and Colleges. Since 2016, the Shandong Provincial Department of education has started the construction of high-level application-oriented universities and the reform of high-level applied majors.

Under this background, the application-oriented colleges must adapt themselves to the new normal development of economy and higher education. Therefore, it is urgent to reform and explore the personnel training mode and mechanism of college-enterprise cooperation. So the construction of the model of college-enterprise cooperation in application-oriented colleges is a hot and difficult problem in the teaching reform of higher education in China. In order to combine the application orientation of the applicationoriented colleges and the demand characteristics of professional talents, we should draw on the advanced educational concepts, clear the training target of professional talents, and optimize the personnel training programs based on the deep college-enterprise cooperation. Especially carry out comprehensive reform and practice of the important links of professional development, such as teaching team, production and teaching integration, teaching management and curriculum teaching materials, to create an upgraded version of "application type", and to promote the overall upgrading of college-enterprise cooperation.

\section{CONSTRUCTION ON THE MODE OF DEEP COLLEGE-ENTERPRISE COOPERATION IN APPLICATION-ORIENTED COLLEGES IN CHINA}

In the following, based on analysis of the mode and mechanism of cooperation of our application-oriented colleges and taking into account the current lack of cooperation, we will put forward a kind of deep college-enterprise cooperation mode, and study the working mechanism, the corresponding work standards and evaluation system, to enhance the level of cooperation.

\section{A. Analyze the demand and ability of talents in enterprises}

In the following we take computer majors as an example. The employment of computer majors in colleges is oriented to information technology research and services, but the main channel of employment is IT enterprises. Therefore it is necessary to investigate the current situation and development trend of China's information industry, especially IT Enterprises. The work includes the following aspects:

- Hierarchical classification of IT Enterprises.

- Classify jobs

- Analyze talent demand for different positions.

- Methods of employment assessment.

- Analyze the market demand and development potential of the enterprises.

On this basis, we construct information database of IT enterprises and growth archives of college students.

\section{B. Construction of talent training program and curriculum quality standards based on deep college-enterprise cooperation}

Although the colleges in China have explored college-enterprise cooperation for many years, there are still some problems in the implementation effect. The " $3+1 "$ model is adopted by most colleges and Universities. Driven by the short-term benefits of the enterprise, most of the trained students are skilled employees at the operational level. Therefore, the development potential of their students is limited, and they do not meet the needs of high-level application-oriented talents to solve complex problems, nor have they achieved the integration of teaching and research in scientific and technological innovation. Therefore, in order to cultivate, share and achieve a win-win situation, it is urgent to explore and practice a scientific and rational mode of college-enterprise cooperation in the field of personnel training and the development of both colleges and enterprises. Deep college-enterprise cooperation is a comprehensive mode of cooperation, that is, colleges and enterprises carry out all-round cooperation not only in personnel training cooperation, but also in scientific research, product development, management and social services. This re flects the following aspects:

- The combination of the enterprise model and the college model.

- The integration of school culture and enterprise culture can realize the dual development of students' humanistic quality and professional quality.

- The integration between college teachers and enterprise engineers.

- The integration of colleges and enterprises in the innovation of teaching and research achieves a win-win development and breakthrough.

First of all, we design a model of deep cooperation between colleges and enterprises, which includes the related conditions, objectives, tasks, time, place and so on. The key is the formulation of talent training program. Especially, the pertinence and application of the major are emphasized in the course setting. Under the guidance of international engineering education professional certification, according to the requirements of the national teaching standards, the foundation and positioning of the college, driven 
by the enterprise demand, we should stress ability orientation and reverse construct curriculum system. According to the demand of enterprise talents, it comes down to the technical application ability, the basic theory knowledge and the comprehensive quality requirements of the industry. And then reverse design personnel training program, reverse looking for required lead courses and support courses. According to the needs of talents in different positions of enterprises, we design different ways to train students. On the basis of the cultivation of professional quality, the teaching content is optimized and the dynamic curriculum module is constructed. Secondly, we formulate the teaching plan and curriculum quality standards for each major. The public courses and basic courses are mainly implemented by colleges, while specialized courses and professional quality courses are mainly implemented by enterprises. Adhere to the industry-oriented, the enterprise evaluation standards and industry technology will be integrated into the teaching process management and professional development management. Then realize the synchronization between professional development and industry advanced technology development, and achieve the unity of educating people and talent's training.

\section{Constructing the working mechanism of deep college-enterprise cooperation}

Cooperation between colleges and enterprises is the way of educating people with dual threads of knowledge and ability. Deep college-enterprise cooperation, that is, to achieve the direction of both colleges and enterprises, goals and demands are consistent. The goal is to form a "one relationship acommunity". Then this requires the joint efforts of both colleges and enterprises. For colleges, cooperation with enterprises is a reform and innovation. We should design from the overall and systematic point of view so as to implement and promote the comprehensive reform and establish a management system suitable for the cooperation between colleges and enterprises.

Deep college-enterprise cooperation is a systematic project, including quality, factors, systems, mechanisms and other aspects . The quality includes the whole process, the whole staff, the organization, the service and so on. The factors include subject, carrier, process, environment, result, etc. The system includes goals, responsibilities, standards, actions, systems, evaluations, etc. The internal mechanism of college-enterprise cooperation means the internal working style of college-enterprise cooperation. It includes the relation of each component, the relation of mutual change and mutual influence. The whole includes two major aspects, namely power mechanism and operation mechanism. Specifically, it can be divided into goals, interests, decision-making, motivation, quality control, quality report, report tracking, accountable effect, technology development, students' development, resources sharing mechanism (personnel, equipment, information and culture, etc.) and a series of rules of operation. Our task is to explore the training law of applied talents, to study the goals and work flow of college-enterprise cooperation, and to construct a relative scientific and reasonable standards of college-enterprise cooperation. On this basis, we should reform the methods and means of personnel training, pay attention to the assessment and evaluation of process and practical ability, and promote evaluation of multi subjects. The performance evaluation of college-enterprise cooperation includes student evaluation, self-evaluation of college and enterprise, mutual evaluation, and the third-party evaluation.

\section{Research and design on information platform of deep college-enterprise cooperation}

College-enterprise cooperation is a comprehensive open college running mode. College or enterprise as a link can form a global or regional college-enterprise cooperation network, forming the sharing of resources between colleges and enterprises. We will research and design a information platform of college-enterprise cooperation, and study the construction and utilization of the college-enterprise resources pool. The college-enterprise resource pool includes: condition pool, talent pool, teacher pool, curriculum pool, project pool, professional pool, information pool, cultural pool, etc.. In addition, we should innovate the management means of college-enterprise cooperation, and realize the process control and performance evaluation of college-enterprise cooperation.

The above research is related to the whole process of collaborative education between colleges and enterprises. It forms a closed loop. Each link supports each other. The college-enterprise cooperation training program and its work mechanism is the focus of our research.

\section{REFERENCES}

[1] Yunjie Tu, Yang Bai, On the Reform of practical teaching in computer majors based on the application-oriented talents training target, Journal of Hulunbeier University,2016, pp. 107-109.

[2] Ting Yu, Jianhua Wang, Study on College-Enterprise Cooperation in Practical Teaching of Computer Majors, Computer Education, 2009 , pp. 47-49.

[3] Lina He, Strategies of Integrating Corporate Culture into Higher Vocational Colleges under the Mode of School-Enterprise Cooperation, Journal of Kaifeng Institute of Education, 2014, pp. 181-183.

[4] Peiming Fu, On the integration of campus culture and corporate culture under the mode of school-enterprise cooperation, Chinese Vocational and Technical Education, 2011, pp. 26-28. 